\title{
Evaluating Total Factor Productivity Growth of Commercial Banks in Sri Lanka: An Application of Malmquist Index
}

\author{
A.Thayaparan, \\ Vavuniya Campus of the University of Jaffna, Sri Lanka \\ T.Pratheepan, \\ Vavuniya Campus the University of Jaffna, Sri Lanka
}

Received: April 22, 2014

doi:10.5296/jmr.v6i3.5513
Accepted: June 10, 2014

Published: July 1, 2014

URL: http://dx.doi.org/10.5296/jmr.v6i3.5513

\begin{abstract}
This study focuses on total factor productivity growth and its decomposition of commercial banks in Sri Lanka. For this purpose, two state banks, Bank of Ceylon and Peoples' bank and four private banks, namely, Commercial bank, Seylan bank, Hatton National Bank and Sampath were selected over the period 2009- 2012. By using Data envelopment analysis (DEA) total factor productivity and its components were measured in terms of efficiency change, technical efficiency change, pure efficiency change and scale change. The data related to interest income and amount of loans which were considered as two outputs and amount of deposits, total assets, number of staff and interest expenses considered as four inputs were collected from annual reports of Colombo Stock Exchange (CSE) in Sri Lanka and were analyzed on the assumption of output oriented method with constant returns to scale. It was found that, all six banks operate averagely at 87.2 percent of overall efficiency and it reveals the less performance of the banks. This less performance was achieved due to the less progress in technical change than efficiency change and the finding highlights that technical change has been the main constraint to achieve a high level of total factor productivity of commercial banks in Sri Lanka. Among the private banks, Seylan bank has the highest efficiency of 1.033 than other banks and among the state banks, Peoples' bank have the values of 0.773than Bank of Ceylon. The overall results concluded that comparatively selected private banks are more efficient than state banks in the study period in Sri Lanka.
\end{abstract}

Keywords: Data Envelopment Analysis, Technical efficiency change, Pure efficiency change, Malmquist index. 


\section{Introduction}

Banking sector plays an important role for economic development in any country and evaluation of efficiency and performance of the banks also is necessary in the modern banking sector. Today, banks are facing many challenges and try to attract their customers in a very competitive market structure. Present technological advancements and globalization also make pressure on the banks to maintain market structure to survive and remain in the competitive banking sector. To achieve these targets, each bank tries to raise its efficiency and the performance by using the inputs effectively. Since 1977, in addition the state banks, various private banks are operating in Sri Lanka has and from the establishment of private banks, banking industry become as a competitive one and each bank introduced various facilities and services to the customers to increase their profits and performance well.

Objectives of this study are to measure total factor productivity and examine its main components and different efficiencies based on Malmquist index of two state banks and four private banks operating in Sri Lanka during the period from 2009- 2012.

\section{Literature Review}

Denf Chen-guo, Liu Ting, Wu Jie, (2007) has analyzed the efficiency analysis of China's Commercial Banks Based on DEA: Negative Output Investigation and their findings illustrated that the super-DEA model is unable to explain in Industrial and Commercial Bank of China and Construction Bank of China according to the super-efficiency value, which suggests that the two banks both perform well and therefore, both rank the first in the list.

Jehovaness Aikaeli (2008) examined the Commercial Banks Efficiency in Tanzania and he has found that banksin Tanzania still have reasons to improve their performance.

Sunil Kumar \& Rachita Gulati (2008), using data envelopment analysis, examined the technical, pure Technical, and scale efficiencies in Indian public sector banks and the study concluded that the exposure of the banks to off-balance sheet activities has a strong and positive impact on the overall technical efficiency of banks.

Another research carried out by Evren Ayranci regarding the efficiency of the private commercial banking sector in Turkey: a managerial approach and the results showed that annually, the relative efficiency of the sector has decreased overall irrespective of the inclusion of the data for general managers; foreign banks have displayed greater efficiency compared to domestic banks when financial efficiency is considered alone; domestic and foreign banks have the same efficiency level when the data for general managers are considered; and the annual relative efficiency figures for the sector demonstrate vast amounts of fluctuation during periods of economic crisis, again with or without the data for general managers.

Valentin Z. Toçi(2009) analyzed the efficiency of banks in south- east Europe: With special reference to Kosovo and their results revealed that argued that the overall efficiency improvement has originated from the change in technology rather than scale and technical efficiency, and banks on average have not been able to catch-up with best performers, thus widening the efficiency gap.

Technical Efficiency of Indonesian Commercial Banks: An Application of Two-Stage DEA was analyzed by Tessa Vanina Soetanto and Ricky and they have found that Indonesian 
commercial banks could improve their technical efficiency by $10.5 \%$ on average and the scale inefficiency is dominating over pure technical inefficiency. The commercial state-owned banks are showing perfect efficiency during the period of study, and proven to be more efficient compared to the commercial private banks.

Another study reviewed by Versha Mohindra, A.M., \& Gian Kaur,S.(2009) on total factor productivity of regional rural banks in India using a Malmquist approach and they found that total factor productivity change in performance of regional rural banks averaged at $1.3 \%$ during 1992- 2007.

Vikas Choudhary, Sanjeev Gupta, \& Sumantandon,S.(2009 ) evaluated the total factor productivity of public sector banks in India using a Malmquist approach and their results showed that total factor productivity change in performance of nationalized banks averaged at 2.2 percent during 1992-93 to 2006-07.

Mohammad Hanif Akhtar (2010) examined that X-Efficiency Analysis of Pakistani Commercial Banks in Pakistan for the years from 2001 to 2006 by using Data Envelopment Analysis. The findings revealed that foreign banks tend to perform better than those of the local banks in Pakistan, both private and public. However, private local banks perform better than those of their counterparts in the public sector.

Regarding to the data envelopment analysis, another research carried out based on The Relative Efficiency of Jordanian Banks and its determinants using data envelopment analysis by Moh'd Mahmoud Ajlouni, Mohammad Waleed Hmedat and Waleed Hmedat(2011). According to that, their findings proved that the results indicate that average efficiency score of the banks is high and stable over time and also showed that the relative efficiency of larger banks significantly outperforms smaller and medium size banks, indicating that bank size is a determinant of efficiency.

Ashish Kumar \& Vikas Batra (2012) analyzed in their survey of Indian banking industry during the post liberalization period of 2006-2011, by applying Malmquist Productivity Index method and they have found that Indian banking industry experienced stagnation in technological progress. Further, out of 74 banks chosen for the study 13 banks have witnessed productivity loss and remaining 61 banks have shown productivity progress.

According to Majid Karimzadeh (2012) their findings reveal that the mean of cost efficiency, technical efficiency, and allocative efficiency are $0.991,0.995$, and 0.991 in various returns to scale model and 0.936, 0.969 and 0.958 in other model, respectively using DEA approach.

Anastasios D. Varias and Stella Sofianopoulou(2012) examined the Efficiency evaluation of Greek commercial banks using data envelopment analysis and their results indicate several inefficiencies that have no direct relation to the profitability of such institutions.

\section{Methodology}

The study considered six commercial banks covering two state banks namely, Bank of Ceylon and People's bank and four private banks such as, commercial bank, Seylan bank, Hatton National Bank and Sampath bank which are operating in Sri Lanka during the period from 2009 to2012. Data for the variables of interest income and amount of loans which were considered as two outputs and amount of deposits, total assets, number of staff and interest expenses were considered as four inputs were collected from various annual reports and 
publications of Colombo Stock Exchange (CSE) in Sri Lanka and they were analyzed based on output oriented method with constant returns to scale.

This study uses non-parametric approach namely, data envelopment analysis (DEA) to estimate various components of Malmquist index such as, efficiency change, technical change, pure efficiency change and scale change of commercial banks in Sri Lanka. This method developed by Charnes et al (1978) is a linear programming based technique occasionally it is called as frontier analysis and also it is a performance measurement technique which can be used for analyzing the relative efficiency of productive units having the multiple inputs and outputs. DEA is a methodology for examining the relative efficiency, based on selected multiple inputs and outputs data which called as decision making units (DMUs). From the set of available data, DEA identifies relative efficient units which define the efficiency frontier and lies on the curve and evaluate the inefficient of other units which lie below the frontier curve.

Malmquist total factor productivity index calculates the changes in productivity between two points by estimating the ration of the distances of each point relative to a common technology.

Malmquist output oriented total factor productivity change index between the base period

$(\mathrm{t})$ and the following period $(\mathrm{t}+1)$ is defined as:

$$
M\left(y_{t}, X_{t}, y_{t+1}, X_{t+1}\right)=\left[\frac{d_{t+1}\left(Y_{t+1}, X_{t+1}\right)}{d_{t}\left(Y_{t}, X_{t}\right)} X \frac{d_{t}\left(Y_{t+1}, X_{t+1}\right)}{d_{t+1}\left(Y_{t+1}, X_{t+1}\right.}\right]^{1 / 2}
$$

A value of (M) greater than unity implies a positive total factor productivity growth (TFP) growth from period $(\mathrm{t})$ to period $(\mathrm{t}+1)$, otherwise, a value of "M" less than one indicates a TFP decline. Equation (1) represents the geometric mean of two TFP indices and the first index is calculated with respect to period " $t$ " technology, while the second index is evaluated with respect to period “ $t+1$ ” technology.

One advantage of the Malmquist index is that it allows distinguishing between technological change and technical efficiency change. Technological change is represented by shifts in the production frontier and technical efficiency change represented by the movements of firms towards the frontier curve. The measure of technical efficiency scores must be between 0 and1.

Thus, a value of technical efficiency change is greater than unity reflects the movement of the particular inefficient unit towards the constant returns to scale frontier, and is interpreted as efficiency improvement. In contrast, a value of this index is less than unity is explained as the deterioration of efficiency. Similarly, a value of technical change is greater than unity means technological progress or an expansion of the frontier and if the value is less than one represents technological regress or contraction of the frontier.

Following Fare et al. (1993) an equivalent way of writing this index is: 
Total factor productivity change index $=\frac{D^{t}\left(y^{t}, x^{t}\right)}{D^{t+1}\left(y^{t+1}, x^{t+1}\right)} \times\left[\frac{D^{t+1}\left(y_{t+1}, x_{t+1}\right)}{D^{t}\left(y^{t+1}, x^{t+1}\right)} \times \frac{D^{t+1}\left(y^{t}, x^{t}\right)}{D^{t}\left(y^{t}, x^{t}\right)}\right]^{1 / 2}$

Thus, total factor productivity change index $=\{$ Efficiency change $\} X$ Technological change $\}$ and it can be decomposed into two components such as technological change and technical efficiency change and it illustrated as:

$$
\text { Technological change index }=\left[\frac{D^{t+1}\left(y_{t+1}, x_{t+1}\right)}{D^{t}\left(y^{t+1}, x^{t+1}\right)} \times \frac{D^{t+1}\left(y^{t}, x^{t}\right)}{D^{t}\left(y^{t}, x^{t}\right)}\right]^{1 / 2}
$$

and

$$
\text { Technical efficiency change index }=\left[\frac{D^{t+1}(C R S)\left(y_{t+1}, x_{t+1}\right)}{D^{t}(C R S)\left(y^{t}, x^{t}\right)}\right]
$$

Technical efficiency change can be further decomposed into two partitions, namely pure efficiency change which is explained as the technical efficiency catching-up against various returns to scale(VRS) technology frontier, and the other is scale efficiency change which captures the tendency of pure efficient units moving along the boundary or (and) the pure technical inefficient units changing their position in the interior of the boundary towards or further away from constant return portion of the estimated technology. Thus, technical efficiency change is the product of pure change ( $\mathrm{PCH})$ and scale change $(\mathrm{SCH})$ and it can be shown as below:

$$
\text { Pure technical efficiency change index }=\left[\frac{D^{t+1}(\operatorname{VRS})\left(y_{t+1,} x_{t+1}\right)}{D^{t}(\operatorname{VRS})\left(y^{t}, x^{t}\right)}\right]
$$

and

$$
\text { Scale efficiency change index }=\left[\frac{D^{t+1}(C R S)\left(y_{t+1}, x_{t+1}\right)}{D^{t}(C R S)\left(y^{t}, x^{t}\right)}\right] /\left[\frac{D^{t+1}(\operatorname{VRS})\left(y_{t+1,}, x_{t+1}\right)}{D^{t}(\operatorname{VRS})\left(y^{t}, x^{t}\right)}\right]
$$

Hence,

Total factor productivity change $=$ Technological change $*$ Pure efficiency change* Scale change

\section{Results and Discussions}

Descriptive statistics are used to describe the basic features of the data set and they provide simple summaries about the sample and the measures. A detailed description of the basic analytical tools such as mean and standard deviation, maximum and minimum of the variables were used and the descriptive statistics of the variables used in the study period are given in tables from 01 to 06 where deposits, total assets, number of staff and interest expenses considered as four inputs and interest income and loans treated as two outputs for six banks in Sri Lanka. All the six tables are attached in the appendixes. 
According to the tables 01 and 02, mean value of deposits for Bank of Ceylon relatively higher than other banks, but mean value of total assets for People's bank is higher than others. Further, compare with other private banks, the two state banks such as bank of Ceylon and People's bank exhibited higher mean value for deposits. Similarly, in case of total assets also the above two state banks have higher mean value than other private banks. Number of staff indicated by the table 03, its mean value is higher in People's bank while Seylan bank has the higher mean value for interest expenses which shown in the table 04. Still the two state banks have higher number of staff in their banking sector than private banking in Sri Lanka. However, Seylan bank has the higher mean of interest expenses than other private and state banks which shown in table 04.

In the tables 05 and 06, mean value of interest income for People's bank is higher than other banks and Seylan bank has the higher mean value for loans. Among all the banks, Hatton National Bank has less mean of interest income while Sampath bank has less mean of loans during the study period. Under the assumption of constant returns to scale, all the efficiency scores of data envelopment analysis were obtained using the DEAP 2.1software developed by Tim Coelli (1996). This research examined the efficiency measurements of six banks using data envelopment analysis and total factor productivity change and its major components were measured in this study. According to the table 07, average efficiency scores were slightly increased in 2012 than previous years and the trend of efficiency scores were fluctuated for HNB and Sampath banks while rest of other four banks maintain a score of 1.0 from 2010 to 2012. However, on average all the banks maintain their efficiency very close to the optimal level.

Table 07. Average efficiency change for banks

\begin{tabular}{cccc}
\hline Banks & $\mathbf{2 0 1 0}$ & $\mathbf{2 0 1 1}$ & $\mathbf{2 0 1 2}$ \\
\hline COM & 1.000 & 1.000 & 1.000 \\
SEY & 1.000 & 1.000 & 1.000 \\
HNB & 0.963 & 1.083 & 1.000 \\
BOC & 1.000 & 1.000 & 1.000 \\
SAM & 1.000 & 0.889 & 1.125 \\
PEO & 1.000 & 1.000 & 1.000 \\
Average & 0.993 & 0.995 & 1.028 \\
\hline
\end{tabular}

Source: Colombo Stock Exchange, Annual reports

Table 07 shows the scores of average efficiency change for all banks and under the assumption of constant returns to scale output results all banks are technically efficient because they have the technical efficiency scores equal to one in 2012. In year 2011 also all the banks are technically efficiency except Sampath bank which has the score is equal to 0.889. But in 2010, only HNB has the value of score is 0.963 reveals that this bank is technically inefficient but very close to efficiency because of the score value is close to one. In 2011, technical efficiency (TE) of Sampath bank is 0.889 proves that is Sampath bank should be able to increase the interest income and loans by $11.1 \%$ without increasing its inputs. Similarly, in 2010, HNB should be able to increase the interest income and loans by only 3.7\% without increasing the inputs. In 2012, a remarkable thing is that Sampath bank is recognized as most efficient bank because the score of efficiency change is 1.125 which is higher than other five banks. 
Another component of total factor productivity change can be illustrated in terms of technological changes and the results are shown the table 08. The results show that compare with 2010 and 2011, average technical score is higher in 2012, and Sampath bank has the highest score than other banks in the same year. The banks HNB and BOC have the scores of 0.767 and 0.781 reveals that the above two banks should be able to increase the interest income and loans by $23.3 \%$ and $21.9 \%$ respectively without increasing the inputs of deposits, total assets, number of staff and interest expenses.

Table 08. Average technological change for banks

\begin{tabular}{llll}
\hline Banks & $\mathbf{2 0 1 0}$ & $\mathbf{2 0 1 1}$ & $\mathbf{2 0 1 2}$ \\
\hline COM & 0.743 & 0.875 & 1.175 \\
SEY & 0.752 & 1.467 & 0.998 \\
HNB & 0.786 & 1.165 & 0.767 \\
BOC & 0.778 & 0.761 & 0.781 \\
SAM & 0.632 & 0.468 & 2.059 \\
PEO & 1.094 & 0.760 & 0.617 \\
Average & 0.797 & 0.916 & 1.066 \\
\hline
\end{tabular}

Source: Colombo Stock Exchange, Annual reports

The results of average pure efficiency change and scale efficiency change are display in the tables 09 and 10. It shows that, in 2012, pure and scale efficiency changes are almost same except for the Sampath bank indicating that these two efficiency scores have less importance than technological change as a source of inefficiency among all banks. But in terms of average scores, the mean of pure efficiency change (1.020) is slightly higher than mean of scale efficiency change (1.000) proves that contribution of pure efficiency change to the total factor productivity change is higher than scale efficiency change. These findings suggest that inefficiency of the banks is attributed due to the inadequate operating scale or returns to scale only by $2 \%$.

Table 09. Average pure efficiency change for banks

\begin{tabular}{llll}
\hline Banks & $\mathbf{2 0 1 0}$ & $\mathbf{2 0 1 1}$ & $\mathbf{2 0 1 2}$ \\
\hline COM & 1.000 & 1.000 & 1.000 \\
SEY & 1.000 & 1.000 & 1.000 \\
HNB & 0.985 & 1.015 & 1.000 \\
BOC & 1.000 & 1.000 & 1.000 \\
SAM & 1.000 & 0.891 & 1.123 \\
PEO & 1.000 & 1.000 & 1.000 \\
Average & 0.997 & 0.984 & 1.020 \\
\hline
\end{tabular}

Source: Colombo Stock Exchange, Annual reports

Thus, pure efficiency change appears to have contributed to the productivity of Sampath bank and this index did not change in 2012.

Table 10. Average scale efficiency change for banks

\begin{tabular}{clll}
\hline Banks & $\mathbf{2 0 1 0}$ & $\mathbf{2 0 1 1}$ & $\mathbf{2 0 1 2}$ \\
\hline COM & 1.000 & 1.000 & 1.000 \\
SEY & 1.000 & 1.000 & 1.000 \\
HNB & 0.978 & 1.023 & 1.000 \\
BOC & 1.000 & 1.000 & 1.000 \\
SAM & 1.000 & 0.998 & 1.002 \\
PEO & 1.000 & 1.000 & 1.000 \\
Average & 0.996 & 1.003 & 1.000 \\
\hline
\end{tabular}

Source: Colombo Stock Exchange, Annual reports 
In the table 10 shows that, scale efficiency change may have slightly contributed to the productivity of Sampath bank which is an indication of Sampath bank has benefitted from increasing returns to scale. Rest of other banks have the score of one indicates that those banks have benefitted from constant returns to scale.

Table 11. Average total factor productivity change

\begin{tabular}{lccl}
\hline Banks & $\mathbf{2 0 1 0}$ & $\mathbf{2 0 1 1}$ & $\mathbf{2 0 1 2}$ \\
\hline COM & 0.743 & 0.875 & 1.175 \\
SEY & 0.753 & 1.467 & 0.998 \\
HNB & 0.758 & 1.210 & 0.767 \\
BOC & 0.778 & 0.761 & 0.781 \\
SAM & 0.632 & 0.416 & 2.317 \\
PEO & 1.094 & 0.760 & 0.617 \\
Average & 0.793 & 0.914 & 1.109 \\
\hline
\end{tabular}

Source: Colombo Stock Exchange, Annual reports

Average total factor productivity change was estimated and compared among the banks in the above table. The results show that average total factor productivity change has increased only for commercial bank continuously from 2010 to 2012 and for other banks it was fluctuated over the same period. But compare with commercial bank, Sampath bank has an improvement in average total factor productivity change by $131.7 \%$ in 2012 .

Table 12 depicts the yearly average decomposed of total factor productivity change or Malmquist productivity index of the six banks and the composition of Malmquist index was decomposed into the efficiency change (effch) and technical change (techch) indices. In order to identify the changes in scale and pure efficiency, efficiency change were further classified into pure (pech) and scale efficiency changes (sech). Table 12 indicates that six banks in the panel, have experienced the negative performance of total factor productivity change and its growth was declined averaged at 12.8\% during 2010 - 2012. The decomposition of total factor productivity change showed that the mean technical progress has decreased at $12.8 \%$ whereas average technical efficiency has constant during that period. It observed that there was a decrease in total factor productivity change in the years 2010 and 2011, but it has increased slightly at $0.09 \%$ in 2012 . Due to the improvement of efficiency change averaged at $2 \%$, total factor productivity index has increased slightly in 2012. Decomposition of efficiency change into two components such as pure efficiency change and scale change measures the performance only due to the managerial activity and scale efficiency respectively and over the study period these indices have constant growth.

Table 12. Annual means of Malmquist index for the banks

\begin{tabular}{llllll}
\hline Year & effch & techch & pech & sech & tfpch \\
\hline 2010 & 0.994 & 0.787 & 0.997 & 0.996 & 0.782 \\
2011 & 0.987 & 0.860 & 0.983 & 1.003 & 0.849 \\
2012 & 1.020 & 0.981 & 1.019 & 1.000 & 1.001 \\
Mean & 1.000 & 0.872 & 1.000 & 1.000 & 0.872 \\
\hline
\end{tabular}

Source: Colombo Stock Exchange, Annual reports

Total factor productivity change indices or Malmquist indices for the banks in Sri Lanka are presented in table 13. The highest growth rate has been observed for the Seylan bank (3.3\%) while the negative growth rate recorded for Bank of Ceylon (22.7\%). This was happened 
entirely due to the technical changes in these banks. Since efficiency change, pure efficiency change and scale change were not change while total factor productivity indices changed significantly due to the technical changes only.

Table13. Average Malmquist index of the banks for 2010 -2012

\begin{tabular}{cccccc}
\hline Banks & effch & techch & pech & sech & tfpch \\
\hline COM & 1.000 & 0.914 & 1.000 & 1.000 & 0.914 \\
SEY & 1.000 & 1.033 & 1.000 & 1.000 & 1.033 \\
HNB & 1.000 & 0.889 & 1.000 & 1.000 & 0.889 \\
BOC & 1.000 & 0.773 & 1.000 & 1.000 & 0.773 \\
SAM & 1.000 & 0.848 & 1.000 & 1.000 & 0.848 \\
PEO & 1.000 & 0.801 & 1.000 & 1.000 & 0.801 \\
Mean & 1.000 & 0.872 & 1.000 & 1.000 & 0.872 \\
\hline
\end{tabular}

Source: Colombo Stock Exchange, Annual reports

Average indices over the last three year periods in Table 13 above show that only Seylan bank seems to exhibit improvement in total factor productivity (TFPCH). While commercial bank, HNB and Sampath bank show slight increases, Bank of Ceylon and Peoples' Bank show a decline in productivity. It appears that lower trend of total factor productivity growth may have come from technological change (techch) rather than technical efficiency change (effch), as indicated that average technical change for all banks over the years to be less than one except Seylan bank. The average efficiency change, on the other hand, had constant value of one over the years for all banks. Overall, Seylan bank exhibited improvements while all other banks showed lower score of technical efficiency over the covered period.

\section{Conclusion}

This study attempts to investigate the efficiency of commercial banks in Sri Lanka during the period 2009 -2012 using data envelopment analysis. This method enabled to distinguish between the different components of total factor productivity change. The empirical findings reveal that in terms of Malmquist or total factor productivity index, Seylan bank has the highest efficiency of 1.033 indicated that it has increased at 3.3\% and other banks have less than one indicated that they have negative growth in total factor productivity. In addition, average Malmquist or total factor productivity index show that it was declined in during the period 2010 - 2012 by $12.8 \%$ due to the technological change than efficiency change, pure change or scale change. The overall results of total factor productivity index concluded that Seylan bank has more efficient by 3.3\% and Bank of Ceylon has less efficient by $22.7 \%$ as compared to other banks and the results confirmed that comparatively selected private sector banks are more efficient than state banks during the study period in Sri Lanka.

\section{References}

Anastasios D. Varias, \& Stella Sofianopoulou. (2012). Efficiency evaluation of Greek commercial banks using data envelopment analysis Lecture Notes in Management Science. 4th International Conference on Applied Operational Research, Proceedings.

Ashish Kumar, \& Vikas Batra, A. (2012). Efficiency Analysis of Indian Banks (2006-2011): An Application of Malmquist Productivity Index.

Charnes, A., Cooper, W., \& Rhoades, E. (1978). Measuring efficiency of decision Making 
Units. European Journal of Operational Research, 2, 429-44. http://dx.doi.org/10.1016/0377-2217(78)90138-8

Deng Chen-guo, Liu Ting, \& Wu Jie, (2007). Efficiency Analysis of China's Commercial Banks Based on DEA: Negative Output Investigation.

Evren Ayranci. The efficiency of the private commercial banking sector in Turkey: a managerial approach.

Fare, R., Grosskopf, S., Norris, M., \& Zhang, Z. (1994). Productivity Growth, Technical Progress and Efficiency Change in Industrialized Countries. The American Economic Review, 84, 66-83.

Jehovaness Aikaeli, (2008). Commercial Banks Efficiency in Tanzania. A Paper Presented in a CSAE Conference on "Economic Development in Africa".

Majid Karimzadeh. (2012). Efficiency Analysis by using Data Envelop Analysis Model: Evidence from Indian Banks. Int. J Latest Trends Fin. Eco. Sc, 2(3).

Mohammad Hanif Akhtar. (2010). X-Efficiency Analysis of Pakistani Commercial Banks. International Management Review, 6(1), 12-24.

Moh'd Mahmoud Ajlouni, Mohammad Waleed Hmedat, \& Waleed Hmedat. The Relative Efficiency of Jordanian Banks and its Determinants Using Data Envelopment Analysis.

Sunil Kumar, \& Rachita Gulati. (2008). An Examination of Technical, Pure Technical, and Scale Efficiencies in Indian Public Sector Banks using Data Envelopment Analysis. Eurasian Journal of Business and Economics, 1(2), 33-69.

Tessa Vanina Soetanto, \& Ricky. Technical Efficiency of Indonesian Commercial Banks: An Application of Two-Stage DEA.

Valentin Z. Toçi. Efficiency of Banks in South- East Europe: With Special Reference to Kosovo.

Versha Mohindra, A.M., \& Gian Kaur,S. (2009). Total Factor Productivity of Regional Rural Banks in India: A Malmquist Approach.

Vikas Choudhary, Sanjeev Gupta, \& Sumantandon,S. (2009). Total Factor Productivity of Public Sector Banks in India: A Malmquist Approach.

\section{Appendixes}

Appendix 1. Descriptive statistics for deposits

\begin{tabular}{lllll}
\hline Banks & Mean & $\begin{array}{c}\text { Standard } \\
\text { Deviation }\end{array}$ & Minimum & Maximum \\
\hline COM & 302198 & 69811 & 234745 & 390569 \\
SEY & 122101 & 18201 & 104816 & 146727 \\
HNB & 277100 & 58059 & 216676 & 347859 \\
BOC & 556979 & 119533 & 408607 & 693441 \\
SAM & 179719 & 51358 & 126091 & 243575 \\
PEO & 523119 & 124418 & 396158 & 683951 \\
\hline
\end{tabular}

Source: Colombo Stock Exchange, Annual reports 
Appendix 2. Descriptive statistics for total assets

\begin{tabular}{lllll}
\hline Banks & \multicolumn{1}{c}{ Mean } & \multicolumn{1}{c}{$\begin{array}{c}\text { Standard } \\
\text { Deviation }\end{array}$} & Minimum & Maximum \\
\hline COM & 411362 & 82885 & 322315 & 511743 \\
SEY & 158150 & 21746 & 132764 & 183662 \\
HNB & 356696 & 72575 & 280289 & 446302 \\
BOC & 550396 & 321666 & 104822 & 838273 \\
SAM & 225811 & 66736 & 156162 & 308681 \\
PEO & 639761 & 173375 & 476245 & 873107 \\
\hline
\end{tabular}

Source: Colombo Stock Exchange, Annual reports

Appendix 3. Descriptive statistics for staff

\begin{tabular}{lllcc}
\hline Banks & Mean & $\begin{array}{c}\text { Standard } \\
\text { Deviation }\end{array}$ & Minimum & Maximum \\
\hline COM & 4380 & 237 & 4071 & 4602 \\
SEY & 3392 & 335 & 3061 & 3733 \\
HNB & 4479 & 181.2 & 4302 & 4679 \\
BOC & 7912 & 306 & 7538 & 8204 \\
SAM & 2940 & 489 & 2388 & 3455 \\
PEO & 8334 & 429 & 7823 & 8863 \\
\hline
\end{tabular}

Source: Colombo Stock Exchange, Annual reports

Appendix 4. Descriptive statistics for interest expenses

\begin{tabular}{lllll}
\hline Banks & Mean & $\begin{array}{l}\text { Standard } \\
\text { Deviation }\end{array}$ & Minimum & Maximum \\
\hline COM & 22831 & 5159 & 18328 & 29830 \\
SEY & 48614 & 41357 & 12120 & 85290 \\
HNB & 19160 & 4694 & 14703 & 25368 \\
BOC & 41346 & 12592 & 31200 & 59701 \\
SAM & 13889 & 4460 & 9953 & 20269 \\
PEO & 40462 & 14341 & 30635 & 61328 \\
\hline
\end{tabular}

Source: Colombo Stock Exchange, Annual reports

Appendix 5. Descriptive statistics for interest income

\begin{tabular}{lllcr}
\hline Banks & Mean & $\begin{array}{l}\text { Standard } \\
\text { Deviation }\end{array}$ & Minimum & Maximum \\
\hline COM & 40427 & 8310 & 34740 & 52685 \\
SEY & 19938 & 2977 & 16596 & 23623 \\
HNB & 3638 & 7554 & 30249 & 47347 \\
BOC & 65041 & 20479 & 50843 & 95022 \\
SAM & 23110 & 5972 & 18477 & 31882 \\
PEO & 66476 & 12781 & 56534 & 85241 \\
\hline
\end{tabular}

Source: Colombo Stock Exchange, Annual reports

Appendix 6. Descriptive statistics for loans

\begin{tabular}{lllll}
\hline Banks & Mean & $\begin{array}{l}\text { Standard } \\
\text { Deviation }\end{array}$ & Minimum & Maximum \\
\hline COM & 262365 & 98226 & 161329 & 372915 \\
SEY & 481226 & 423828 & 106390 & 890908 \\
HNB & 239856 & 58863 & 177229 & 310334 \\
BOC & 467104 & 188765 & 265065 & 691899 \\
SAM & 148530 & 50921 & 92189 & 208184 \\
PEO & 428542 & 142092 & 283760 & 611414 \\
\hline
\end{tabular}

Source: Colombo Stock Exchange, Annual reports 